\title{
Effect of Liming and Mineral Fertilization on the Nickel Content in Potato Tubers (Solanum tuberosum L.) and Green Biomass of Fodder Sunflower (Helianthus annuus L.) Cultivated on Loessial Soil
}

\author{
Janina Kaniuczak', Małgorzata Nazarkiewicz ${ }^{1 *}$, Edmund Hajduk', \\ Stanisław Właśniewski' , Jan Gąsior ${ }^{1}$ \\ 1 Department of Soil Science, Environmental Chemistry and Hydrology, Faculty of Biology and Agriculture, \\ University of Rzeszów, Zelwerowicza 8B, 35-601 Rzeszów, Poland \\ * Corresponding author's e-mail: nazarm@ur.edu.pl
}

\begin{abstract}
The publication presents the results of the research on the nickel content in potato tubers and green mass of fodder sunflower grown on a constant fertilization field on lessive soil developed from the loess located at the Rzeszów Foothills. The experiment established by randomized block design used a four-year crop rotation, which included potatoes, spring barley, fodder sunflower, and winter wheat. Mineral NPK fertilization was used on a background of constant $\mathrm{Mg}$ as well as $\mathrm{Ca}$ and $\mathrm{Mg}$ fertilization (liming). The nickel content in crops was determined by means of FAAS technique (Hitachi, Z 2000) after samples digestion in a mixture of $\mathrm{HNO}_{3}: \mathrm{HClO}_{4}: \mathrm{H}_{2} \mathrm{SO}_{4}$ at 20:5:1 ratio. A decrease of the nickel concentration in potato tubers and in green matter of fodder sunflower due to liming was observed. Mineral nutrition (regardless of liming) did not considerably affect the element content in potato tubers, yet it was significant for the metal content in green mass of sunflower. It was shown that the interaction of liming treatment with mineral fertilization contributed to the lowering of nickel concentration in test crops, especially in the green matter of the fodder sunflower (most of limed fertilization objects), while in potato tubers - to a lesser extent.
\end{abstract}

Keywords: liming, mineral fertilization, nickel, potato tubers, green biomass of fodder sunflower

\section{INTRODUCTION}

Nickel is one of the microelements that is needed by plants in trace amounts and does not play any essential metabolic functions. Although it is counted as a nutrient, a few plant species respond with negative symptoms of its deficiency [Rosen \& Eliason 2005]. It is a component of some enzymes and has a positive effect on the assimilation of free nitrogen by microorganisms [Liu et al. 2011]. It is considered as a necessary element for the development of higher plants, amongst others, through the influence on dehydrogenase, hydrogenase or urease activity, because its deficiency can cause the accumulation of toxic urea at plants [Hänsch \& Mendel 2009].

On the other hand, the excessive content of this element in a plant is toxic to many metabolic functions, restricting the growth and development
[Koszelnik-Leszek 2003, Rosen \& Eliason 2005, Chen et al. 2009, Sharma \& Dhiman 2013]. Low nickel concentrations stimulate germination and growth of sunflower plants, while at the higher ones, the germination intensity was reduced [Jadia \& Fulekar 2008]. The toxic effects of nickel prevent the starch conversion into sugars and proteins into amino acids, which provides the energy for the growth of the sunflower seedlings and its further development [Ashraf et al. 2011].

Contamination of soil environment with nickel led to a reduction in the amount of chlorophyll and increasing the content of this element in sunflower leaves, as well as weakening the physiological activity parameters of roots, including the reduction of their capacity and the ability to take up the water and mineral salts [Szymańska \& Matraszek 2005]. Reducing the amount of chlorophyll in the sunflower leaves was also confirmed 
by Mukhtar et al. [2010]. Ahmad et al. [2011] showed the reduction of macro- and microelements in leaves and seed of sunflower, which is important for the plant growth and development, as a result of the nickel addition to the soil environment. A similar effect resulted in lowering the levels of iron and zinc in the stems of common sunflower [Mohammadzadeh et al. 2014]. The addition of nickel sulfate caused an increase in the nickel content in the leaves and roots of common sunflower [Najafi et al. 2011].

Like in the case of the sunflower, low amounts of the element showed a positive influence on the potato growth [Zornoza et al. 1999]. The studies performed by Shukla [2010] revealed a harmful effect of high nickel doses on the production and quality of potato. It contributed to negative changes in sugars, starch, and protein contents in tubers. The nickel excess in potatoes caused chlorosis and necrosis of young leaves, growth delay and deterioration of zinc and iron concentrations [Shukla \& Gopal 2009].

The nickel concentration in potato tubers can be affected by mineral NPK nutrition [Pakhnenko et al. 2009], also in combination with organic fertilization [Šrek et al. 2010, Šrek et al. 2012] and soil pH [Stegen et al. 2002, Właśniewski 2003, Srek et al. 2010]. Soil acidity is one of the main factors that affect the nickel solubility in soil solution, its availability for plants and thus human health [Öborn et al. 1995]. The presence of low nickel contents in an environment (soil and plants) has no unfavorable effects on human health, while its accumulation in larger quantities may be harmful for people [Stasinos \& Zabetakis 2013].

The aim of the study was to determine the influence of liming and mineral fertilization on the nickel content in potato tubers and green mass of fodder sunflower grown, respectively, in four and three rotations on loessial soil.

\section{MATERIAL AND METHODS}

The research on the effects of liming (A) and mineral fertilization NPK (B) on the nickel content in potato tubers and green matter of fodder sunflower grown in crop rotation: winter wheat - potatoes - spring barley - sunflower fodder, has been carried since 1986 on a static fertilizing field of the University of Rzeszow in Krasne near Rzeszow situated on Rzeszow Foothills $\left(50^{\circ} 02^{\prime} \mathrm{N}\right.$; $22^{\circ} 03^{\prime}$ E, 220 m a.s.1.).
The soil, on which the research was carried out, was formed from loess of grey-brown podzolic-type (Haplic luvisol) and demonstrated the granulometric composition of silt-loam. Prior to the experiment (1986 year), the soil was characterized by a very high acidification (with low $\mathrm{pH}$ values: $\mathrm{pH}_{\mathrm{KCl}}=3.92, \mathrm{pH}_{\mathrm{H} 2 \mathrm{O}}=4.93$ in the plough humus layer (Ap) and $\mathrm{pH}_{\mathrm{KCl}}=3.89$, $\mathrm{pH}_{\mathrm{H} 2 \mathrm{O}}=4.90$ in the enrichment layer (Bt), with considerable values of hydrolytic acidity: $4.87 \mathrm{cmol}^{(+)} \mathrm{kg}^{-1}$ in the Ap layer and

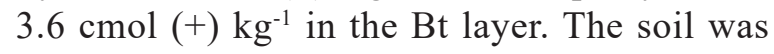
low in the available $\mathrm{P}$ and $\mathrm{K}$, but moderately rich in the available magnesium. The soil contained $0.087 \%$ total $\mathrm{N}$ and $0.76 \%$ organic C [Kaniuczak 1998]. The content of nickel in the total and soluble forms in $1 \mathrm{M} \mathrm{HCl} \mathrm{dm}^{-3}$ amounted to, respectively: $10.40 \mathrm{mg} \mathrm{kg}^{-1}$ and $0.71 \mathrm{mg} \mathrm{kg}^{-1}$ in the Ap layer and $27.90 \mathrm{mg} \mathrm{kg}^{-1}$ and $0.94 \mathrm{mg} \mathrm{kg}^{-1}$ in the Bt layer, which corresponds to its natural contents in the soil.

The experiment was set up in a random subblock design with four replicates. The first variable factor was liming $\left(\mathrm{A}_{2}\right)$ or its lack $\left(\mathrm{A}_{1}\right)$, while the second one consisted of different doses of mineral fertilization with constant magnesium nutrition. The following crops were cultivated in the rotation system: potato, spring barley, fodder sunflower (fodder cabbage in the $1^{\text {st }}$ crop rotation cycle) and winter wheat. The study covered 4 crop rotation cycles.

The basic doses of mineral fertilization $\mathrm{N}_{1} \mathrm{P}_{1} \mathrm{~K}_{1}$ with constant magnesium nutrition were as follows: potato: $\mathrm{N}_{1}=120 \mathrm{~kg} \mathrm{~N}$, $\mathrm{P}_{1}=43.6 \mathrm{~kg} \mathrm{P}, \mathrm{K}_{1}=132.8 \mathrm{~kg} \mathrm{~K} \mathrm{ha}^{-1}$, spring barley: $\mathrm{N}_{1}=80 \mathrm{~kg} \mathrm{~N}, \mathrm{P}_{1}=43.6 \mathrm{~kg} \mathrm{P}, \mathrm{K}_{1}=99.6 \mathrm{~kg} \mathrm{~K} \mathrm{ha}^{-1}$, fodder sunflower: $\mathrm{N}_{1}=100 \mathrm{~kg} \mathrm{~N}, \mathrm{P}_{1}=34.9 \mathrm{~kg} \mathrm{P}$, $\mathrm{K}_{1}=99.6 \mathrm{~kg} \mathrm{~K} \mathrm{ha}^{-1}$, winter wheat: $\mathrm{N}_{1}=90 \mathrm{~kg} \mathrm{~N}$, $\mathrm{P}_{1}=34.9 \mathrm{~kg} \mathrm{P}, \mathrm{K}_{1}=83.0 \mathrm{~kg} \mathrm{~K} \mathrm{ha}^{-1}$. Constant magnesium fertilization was applied before sowing in each experimental sub-block at a $24.1 \mathrm{~kg} \mathrm{Mg} \mathrm{ha}^{-1}$ dose for potato, spring barley and winter wheat, and a $72.4 \mathrm{~kg} \mathrm{Mg} \mathrm{ha}{ }^{-1}$ dose for fodder crops. From 1994 on, the magnesium dose was reduced to $24.1 \mathrm{~kg} \mathrm{Mg} \mathrm{ha}^{-1}$, applied for all experimental crops. Liming with a dose of $4 \mathrm{t} \mathrm{CaO} \mathrm{ha-1}$ was used prior to the experiment and after the harvest of the crop last in a rotation. Mineral fertilizers $\mathrm{NPK}, \mathrm{Mg}$ and $\mathrm{Ca}$ were applied in the forms of ammonium nitrate, triple superphosphate, potassium salt $\mathrm{KCl}(58 \%)$, magnesium sulfate and $\mathrm{CaO}$ or $\mathrm{CaCO}_{3}$ (dose to according 1 value of the hydrolytic acidity). 
The nickel content varied in the applied mineral fertilizers and averaged $0.20 \mathrm{mg} \mathrm{kg}^{-1}$ in magnesium sulphate, $0.37 \mathrm{mg} \mathrm{kg}^{-1}$ in ammonium nitrate, $0.32 \mathrm{mg} \mathrm{kg}^{-1}$ in potassium salt, $1.09 \mathrm{mg} \mathrm{kg}^{-1}$ in calcium carbonate, $2.30 \mathrm{mg} \mathrm{kg}^{-1}$ in calcium oxide and the most in triple superphosphate $6.78 \mathrm{mg} \mathrm{kg}^{-1}$ dry matter [Kaniuczak 1998].

The plant material samples were collected after the potato and fodder sunflower harvest. In dry material, nickel was determined with of FAAS method by means of the atomic spectrophotometric absorbance technique (Hitachi, Z 2000), after digesting the samples in a hot mixture of concentrated acids: $\mathrm{HNO}_{3}: \mathrm{HClO}_{4}: \mathrm{H}_{2} \mathrm{SO}_{4}$ (at a 20:5:1) volume proportion in a Tecator digestion system. The quality assurance of nickel was done by analysing Certified Reference Material (CRM) NCS DC87102, supplied by Analytical Quality Control Services (AQCS), International Atomic Energy Agency (IAEA). The results agree within $\pm 7.5 \%$ of the certified values (certified values $0.69 \pm 0.09 \mathrm{mg} \mathrm{kg}^{-1}$, observed values $0.64 \mathrm{mg} \mathrm{kg}^{-1}$ ).

The results were statistically processed by a two-factor analysis of variance (liming, mineral NPK fertilization) and calculating the lowest significant difference (LSD) with the Tukey's tests at the significance level of $p=0.05$.

\section{RESULTS AND DISCUSSION}

The nickel contents in potato tubers and green biomass of fodder sunflower from individual fertilization objects are shown in Tables 1 and 2. The potato tubers grown in non-limed soil contained $\mathrm{Ni}$ in the range from 2.13 to $4.77 \mathrm{mg} \mathrm{kg}^{-1} \mathrm{DM}$ at average level of $3.14 \mathrm{mg} \mathrm{kg}^{-1}$, while those grown on limed soil from 1.46 to $3.32 \mathrm{mg} \mathrm{kg}^{-1}$ with mean value of $2.08 \mathrm{mg} \mathrm{kg}^{-1}$. The potato cultivars grown on alkaline soils $(\mathrm{pH}=7.5)$ with granulometric composition of silty loams (Turkey) were characterized by a slightly higher nickel content (range: 2.02-3.55 mg kg-1) [Öztürk et al. 2011].

The average nickel content in the potato tubers harvested from limed soil (2.08 $\mathrm{mg} \mathrm{kg}^{-1} \mathrm{~s}$.m.) was significantly lower than that from non-limed objects (3.14 $\left.\mathrm{mg} \mathrm{kg}^{-1} \mathrm{DM}\right)$.

Liming reduces the uptake and content of heavy metals in crops [Błaziak 2007], including potato tubers [Kaniuczak 1997]. The nickel content in potato tubers from the Lublin region plantations depended on the conjunction of soil features, including the particle size composition, humus content, and $\mathrm{pH}_{\mathrm{KCl}}$ value [Bednarek et al. 2006]. The nickel uptake by potato tubers decreased with the increase of $\mathrm{pH}$ and the saturation

Table 1. Content of nickel in the potato tubers cultivated on loessial soil (mean from 4 years), $\left(\mathrm{mg} \mathrm{kg}^{-1} \mathrm{DM}\right)$

\begin{tabular}{|c|c|c|c|c|c|}
\hline \multirow{2}{*}{$\begin{array}{l}\text { Treatments } \\
\text { of fertilizers }(B)\end{array}$} & \multicolumn{2}{|c|}{$A_{1}$} & \multicolumn{2}{|c|}{$\mathrm{A}_{2}$} & \multirow{2}{*}{ Mean $(B)$} \\
\hline & mean & range & mean & range & \\
\hline $\mathrm{N}_{0} \quad \mathrm{P}_{0} \mathrm{~K}_{0}$ & 2.13 & $1.80-2.39$ & 2.25 & $1.77-2.55$ & 2.19 \\
\hline $\mathrm{N}_{0} \quad \mathrm{P}_{1} \mathrm{~K}_{1}$ & 2.68 & $2.02-3.31$ & 2.35 & $1.25-2.72$ & 2.52 \\
\hline $\mathrm{N}_{0,5} \mathrm{P}_{1} \mathrm{~K}_{1}$ & 2.44 & $2.07-2.77$ & 2.43 & $1.95-3.02$ & 2.43 \\
\hline $\mathrm{N}_{1} \quad \mathrm{P}_{1} \mathrm{~K}_{1}$ & 2.56 & $2.27-2.76$ & 2.51 & $1.65-2.81$ & 2.54 \\
\hline $\mathrm{N}_{1,5} \mathrm{P}_{1} \mathrm{~K}_{1}$ & 3.31 & $2.75-3.90$ & 3.26 & $1.91-3.80$ & 3.28 \\
\hline $\mathrm{N}_{1} \mathrm{P}_{0} \mathrm{~K}_{1}$ & 2.68 & $2.83-3.72$ & 2.13 & $1.98-2.50$ & 2.62 \\
\hline $\mathrm{N}_{1} \quad \mathrm{P}_{0,5} \mathrm{~K}_{1}$ & 2.63 & $2.45-3.49$ & 3.32 & $1.05-1.65$ & 2.00 \\
\hline $\mathrm{N}_{1} \quad \mathrm{P}_{1,5} \mathrm{~K}_{1}$ & 2.62 & $2.30-3.75$ & 1.51 & $1.09-1.98$ & 2.07 \\
\hline $\mathrm{N}_{1} \mathrm{P}_{1} \mathrm{~K}_{0}$ & 3.83 & $2.14-2.93$ & 1.96 & $1.57-2.45$ & 2.30 \\
\hline $\begin{array}{lll}N_{1} & P_{1} & K_{0,5}\end{array}$ & 2.95 & $3.11-4.02$ & 1.99 & $1.59-2.90$ & 2.91 \\
\hline $\begin{array}{lll}N_{1} & P_{1} & K_{1,5}\end{array}$ & 3.70 & $2.20-3.35$ & 1.57 & $1.28-2.60$ & 2.26 \\
\hline $\mathrm{N}_{0,5} \mathrm{P}_{0,5} \mathrm{~K}_{0,5}$ & 4.77 & $2.71-4.20$ & 1.46 & $1.08-2.05$ & 2.58 \\
\hline $\mathrm{N}_{1,5} \mathrm{P}_{1,5} \mathrm{~K}_{1,5}$ & 4.76 & $3.46-5.50$ & 1.79 & $1.23-2.40$ & 3.28 \\
\hline $\mathrm{N}_{2} \mathrm{P}_{2} \quad \mathrm{~K}_{2}$ & 4.77 & $3.47-5.21$ & 1.70 & $1.33-2.15$ & 3.09 \\
\hline Mean $(A)$ & 3.14 & - & 2.08 & - & - \\
\hline LSD & \multicolumn{5}{|c|}{$\begin{array}{c}A^{*}=0.95, B=n s \\
A B^{*}=1.20\end{array}$} \\
\hline
\end{tabular}

$\mathrm{A}_{1}-\mathrm{NPK}$ fertilization $+\mathrm{Mg}$ constans, $\mathrm{A}_{2}-\mathrm{NPK}$ fertilization $+\mathrm{MgCa}$ constans,

LSD - lowest significant difference for: A - liming, B - mineral fertilization (irrespective from liming)

$\mathrm{AB}$ - interaction between liming and mineral fertilization

* - significant at $\mathrm{p}=0.05, \mathrm{~ns}-$ no significant differences 
degree of luvisols of Rzeszow Foothills with alkaline cations [Właśniewski 2003]. Similar relationships were observed for the potatoes grown on sandy, sand-loamy and organic soils, where the nickel concentrations increased along with the pH decrease [Öborn et al. 1995]. The increase in the $\mathrm{pH}$ values in the soils developed from loess at a constant cultivation field in Prague did not cause any significant changes in the nickel content in potato tubers [Šrek et al. 2010].

The nickel content in green mass of fodder sunflower grown on non-limed objects varied within $2.03-3.71 \mathrm{mg} \mathrm{kg}^{-1} \mathrm{DM}$ at average value of $2.95 \mathrm{mg} \mathrm{kg}^{-1} \mathrm{DM}$, while in the sunflower biomass originating from individual objects with liming, the contents oscillated from 1.39 to $2.38 \mathrm{mg} \mathrm{kg}^{-1}$ DM (mean level of $1.78 \mathrm{mg} \mathrm{kg}^{-1} \mathrm{DM}$ ). Therefore, liming had a statistically significant impact on lowering the nickel content in green matter of the test plant species.

The procedure reduced the phytoavailability of some heavy metals in the green matter of sunflower [Kaniuczak et al. 2009, Hajduk et al. 2014].

The average nickel content in potato tubers (Table 1) was slightly higher than the average content of this element in the green mass of fodder sunflower (Table 2), both at plants from nonlimed and limed objects. The values of nickel amounts in potato tubers do not fall within the content of the element for this crop grown in Poland [Kabata-Pendias \& Pendias 1999], but there was no exceeding in terms of consumption and fodder usefulness [Kabata-Pendias et al. 1993], like for potato tubers grown on acidic soils of Lublin region [Bednarek et al. 2006]. The regulations issued in Poland and EU [Disposal...2001, Ordinance 2003] do not standardize the nickel content in raw materials nor consumption and fodder products.

Mineral nutrition (B), regardless of liming, did not invoke a statistically significant effect on the nickel content in potato tubers (Table 1). Increasing nitrogen fertilization on a background of constant phosphorus-potassium nutrition (objects: $\mathrm{N}_{0} \mathrm{P}_{1} \mathrm{~K}_{1}, \mathrm{~N}_{0,5} \mathrm{P}_{1} \mathrm{~K}_{1}, \mathrm{~N}_{1} \mathrm{P}_{1} \mathrm{~K}_{1}, \mathrm{~N}_{1,5} \mathrm{P}_{1} \mathrm{~K}_{1}$ ) did not have a univocal tendency of affecting the nickel content in potato tubers. Similarly, increasing the phosphorus fertilization on a background of constant nitrogen-potassium nutrition (objects: $\mathrm{N}_{1} \mathrm{P}_{0} \mathrm{~K}_{1}$, $\mathrm{N}_{1} \mathrm{P}_{0,5} \mathrm{~K}_{1}, \mathrm{~N}_{1} \mathrm{P}_{1} \mathrm{~K}_{1}, \mathrm{~N}_{1} \mathrm{P}_{1,5} \mathrm{~K}_{1}$ ), as well as potassium fertilization on a background of constant nitrogenphosphorus nutrition $\left(\mathrm{N}_{1} \mathrm{P}_{1} \mathrm{~K}_{0}, \mathrm{~N}_{1} \mathrm{P}_{1} \mathrm{~K}_{0,5}, \mathrm{~N}_{1} \mathrm{P}_{1} \mathrm{~K}_{1}\right.$, $\mathrm{N}_{1} \mathrm{P}_{1} \mathrm{~K}_{1,5}$ ) did not show any direct tendency of influencing on the element concentration in potato tubers. Only increasing the NPK fertilization at a proportional increase of nutritional components

Table 2. Content of nickel in green biomass of fodder sunflower cultivated on loessial soil (mean from 3 years), $\left(\mathrm{mg} \mathrm{kg}^{-1} \mathrm{DM}\right)$

\begin{tabular}{|c|c|c|c|c|c|}
\hline \multirow{2}{*}{$\begin{array}{l}\text { Treatments } \\
\text { of fertilizers (B) }\end{array}$} & \multicolumn{2}{|c|}{$A_{1}$} & \multicolumn{2}{|c|}{$A_{2}$} & \multirow{2}{*}{ Mean $(B)$} \\
\hline & mean & range & mean & range & \\
\hline $\mathrm{N}_{0} \mathrm{P}_{0} \mathrm{~K}_{0}$ & 3.49 & $2.78-4.64$ & 2.38 & $1.05-3.33$ & 2.93 \\
\hline $\mathrm{N}_{0} \quad \mathrm{P}_{1} \mathrm{~K}_{1}$ & 3.64 & $2.33-4.88$ & 1.80 & $1.32-2.93$ & 2.72 \\
\hline $\mathrm{N}_{0,5} \mathrm{P}_{1} \mathrm{~K}_{1}$ & 3.57 & $2.42-4.07$ & 1.39 & $0.95-2.08$ & 2.48 \\
\hline $\mathrm{N}_{1} \quad \mathrm{P}_{1} \mathrm{~K}_{1}$ & 3.02 & $2.63-3.68$ & 1.59 & $0.88-2.43$ & 2.30 \\
\hline $\mathrm{N}_{1,5} \mathrm{P}_{1} \mathrm{~K}_{1}$ & 3.71 & $2.88-5.09$ & 2.05 & $1.05-3.10$ & 2.88 \\
\hline $\mathrm{N}_{1} \mathrm{P}_{0} \mathrm{~K}_{1}$ & 2.76 & $2.43-3.11$ & 1.86 & $1.08-2.65$ & 2.31 \\
\hline $\mathrm{N}_{1} \mathrm{P}_{0,5} \mathrm{~K}_{1}$ & 3.30 & $2.95-3.96$ & 1.62 & $0.90-2.33$ & 2.46 \\
\hline $\mathrm{N}_{1} \mathrm{P}_{1,5} \mathrm{~K}_{1}$ & 2.89 & $2.60-3.15$ & 1.60 & $0.95-2.15$ & 2.24 \\
\hline $\mathrm{N}_{1} \mathrm{P}_{1} \mathrm{~K}_{0}$ & 2.60 & $1.95-3.05$ & 1.69 & $0.92-2.56$ & 2.14 \\
\hline $\begin{array}{lll}N_{1} & P_{1} & K_{0,5}\end{array}$ & 2.32 & $1.89-2.65$ & 1.55 & $0.88-2.08$ & 1.94 \\
\hline $\begin{array}{lll}N_{1} & P_{1} & K_{1,5}\end{array}$ & 2.52 & $1.92-3.25$ & 1.89 & $1.19-2.25$ & 2.21 \\
\hline $\mathrm{N}_{0,5} \mathrm{P}_{0,5} \mathrm{~K}_{0,5}$ & 2.41 & $1.80-3.28$ & 2.03 & $1.34-2.65$ & 2.22 \\
\hline $\mathrm{N}_{1,5} \mathrm{P}_{1,5} \mathrm{~K}_{1,5}$ & 3.09 & $2.30-3.68$ & 1.69 & $0.89-2.18$ & 2.39 \\
\hline $\mathrm{N}_{2} \quad \mathrm{P}_{2} \quad \mathrm{~K}_{2}$ & 2.03 & $1.53-3.30$ & 1.85 & $1.26-2.20$ & 1.94 \\
\hline Mean $(A)$ & 2.95 & - & 1.78 & - & - \\
\hline LSD & & & $\begin{aligned}= & 0.90, \\
& \mathrm{AB}^{*}=\end{aligned}$ & & \\
\hline
\end{tabular}

$A_{1}-$ NPK fertilization + Mg constans, $A_{2}-$ NPK fertilization $+M g C a$ constans,

LSD - lowest significant difference for: A - liming, B - mineral fertilization (irrespective from liming)

$\mathrm{AB}$ - interaction between liming and mineral fertilization

$*$ - significant at $\mathrm{p}=0.05$ 
(objects: $\mathrm{N}_{0} \mathrm{P}_{0} \mathrm{~K}_{0}, \mathrm{~N}_{0,5} \mathrm{P}_{0,5} \mathrm{~K}_{0,5}, \mathrm{~N}_{1} \mathrm{P}_{1} \mathrm{~K}_{1}, \mathrm{~N}_{1,5} \mathrm{P}_{1,5} \mathrm{~K}_{1,5}$ ) caused the increase of the metal quantity in potato tubers (Table 1). The mineral NPK fertilization enhanced the nickel amount in the tubers of potato grown on alkaline soil [Pakhnenko et al. 2009]. The studies by Šrek et al. [2010] showed a substantial increase in the nickel content in the potato tubers cultivated on the soil developed from loess, due to the influence of increasing NPK rates in combination with straw addition as well as resulting from high phosphorus and potassium doses along with natural fertilization.

The studies of these authors also showed an increase in the nickel content in potato tubers by using only mineral NPK fertilizers and the tendency of reducing the content of this metal after the introduction of manure without NPK nutrition [Šrek et al. 2012]. Diversified mineral NPK fertilization combined with liming or without this treatment in a 16-year study period, because of the nickel content in mineral fertilizers and fertilization lime [Kaniuczak 1997], could have had a modifying effect on the nickel content in potato tubers (Table 1).

Mineral fertilization (B), independently of liming, significantly influenced the nickel content in green biomass of fodder sunflower (Table 2) causing, among others, its lowering relative to the object without NPK, resulting from a twofold increase of nitrogen, phosphorus and potassium doses (object: $\mathrm{N}_{2} \mathrm{P}_{2} \mathrm{~K}_{2}$ ) and in the object with a decreased potassium rate (object: $\mathrm{N}_{1} \mathrm{P}_{1} \mathrm{~K}_{0.5}$ ). On other objects, mineral fertilization (B) resulted in a trend of nickel decreasing in the green mass of the plant as compared with the control $\left(\mathrm{N}_{0} \mathrm{P}_{0} \mathrm{~K}_{0}\right)$.

Increasing the nitrogen nutrition (relative to basic $\mathrm{N}_{1} \mathrm{P}_{1} \mathrm{~K}_{1}$ rate) on a background of constant phosphorus-potassium fertilization showed a tendency of lowering the nickel concentration in fodder sunflower. Increasing the phosphorus and potassium nutrition on a background of constant contents of other fertilization components had no univocal influence on the nickel concentration in this plant species. The studies by Gunes [2009] performed under other soil and climate conditions indicate the lowering the nickel content in sunflower due to phosphorus fertilization applied.

The many-year research conducted at a constant fertilization field showed a significant statistical interaction of agrochemical treatments, i.e. liming and mineral nutrition (AB), in shaping the nickel content in the potato tubers and green mass of fodder sunflower (Tables 1 and 2).
A reduction in the nickel content in the potato tubers from some fertilization and limed objects as compared to analogous non-limed objects, was recorded (objects: $\mathrm{N}_{1} \mathrm{P}_{1} \mathrm{~K}_{0}, \mathrm{~N}_{1} \mathrm{P}_{1} \mathrm{~K}_{1,5}, \mathrm{~N}_{0,5} \mathrm{P}_{0,5} \mathrm{~K}_{0,5}$, $\mathrm{N}_{1,5} \mathrm{P}_{1,5} \mathrm{~K}_{1,5}$ and $\mathrm{N}_{2} \mathrm{P}_{2} \mathrm{~K}_{2}$ ). There was no univocal tendency in the interaction between these treatments on other objects. In majority of objects, the interaction of liming and mineral fertilization (AB) resulted in lowering the nickel content in the green mass of fodder sunflower grown on limed objects, while in other objects - the tendency of its reduction (Table 2).

\section{CONCLUSIONS}

1. Summing up, it should be stated that liming influenced the statistically significant lowering of the nickel content, both in potato tubers and green mass of fodder sunflower grown several times in the crop rotations on loessial soil.

2. Mineral NPK fertilization (regardless of liming) showed no statistically significant effect on the nickel content in potato tubers. However, there was a trend of the increasing content of this element in potato tubers under the influence of increasing NPK doses at a proportional increase of the applied fertilization rates.

3. Mineral NPK fertilization (regardless of liming) significantly influenced the reduction or tendency to lowering the nickel content in the green mass of fodder sunflower.

4. The interaction of liming and mineral nutrition had a statistically significant effect on shaping the nickel content in potato tubers and green mass of fodder sunflower. Statistically significant lower nickel content in potato tubers was found in some limed fertilization objects, especially those with proportionally increased doses of NPK. Significantly lower nickel content in the green mass of fodder sunflower was shown in most limed fertilization objects, while on other objects, the tendency to reduce the content of this element was recorded.

\section{REFERENCES}

1. Ahmad M.S.A., Ashraf M., Hussain M. 2011. Phytotoxic effects of nickel on yield and concentration of macro- and micro-nutrients in sunflower $(\mathrm{He}$ lianthus tuberosus L.) achenes. J Hazard Mater., 185, 1295-1303. 
2. Ashraf M.Y., Sadiq R., Hussain M., Ashraf M., Ahmad M.S.A. 2011. Toxic Effect of Nickel (Ni) on Growth and Metabolism in Germinating Seeds of Sunflower (Helianthus annuus L.). Biol Trace Elem Res., 143, 1695-1703.

3. Bednarek W., Tkaczyk P., Dresler S. 2006. Heavy metals content as a criterion for assessment of potato tubers. Ann UMCS Sec. E, 61, 121-131 (in Polish).

4. Błaziak J. 2007. Estimation of changesot microelement contents in cereals as influence of calcium and magnesium soil application. Ann UMCS Sec. E, 62(1), 77-84 (in Polish).

5. Chen C., Huang D., Liu J. 2009. Functions and Toxicity of Nickel in Plants: Recent Advances and Future Prospects. VCH Clean, 37(4-5), 304-313.

6. Disposal Commission (EC) No.466/2001.

7. Gunes A. 2009. Determination of mineral element concentrations in wheat, sunflower, chickpea and lentil cultivars in response to $\mathrm{P}$ fertilization by polarized energy dispersive X-ray fluorescence. X-Ray Spectrometry, 38 (5), 451-462.

8. Hajduk E., Kaniuczak J., Właśniewski S., Nazarkiewicz M. 2014. Effect of liming and mineral fertilization on copper content in potato tubers ( $\mathrm{So}$ lanum tuberosum L.) and green matter of fodder sunflower (Helianthus annuus L.) cultivated on loessial soil. J Elem., 19(2), 423-432.

9. Hänsch R., Mendel R.R. 2009. Physiological functions of mineral micronutrients $(\mathrm{Cu}, \mathrm{Zn}, \mathrm{Mn}, \mathrm{Fe}$, $\mathrm{Ni}, \mathrm{Mo}, \mathrm{B}, \mathrm{Cl})$. Current Opinion in Plant Biology, 12 (3), 259-266.

10. Jadia Ch.D., Fulekar M.H. 2008. Phytoremediation: the application of vermicopmost to remove zinc, cadmium, copper, nickel and lead by sunflower plant. Envir Eng Manag J., 7(5), 547-558.

11. Kabata-Pendias A., Motowicka-Terelak T., Piotrowska M., Terelak H., Witek T. 1993. Assessment of the degree of contamination of soils and plants by heavy metals and sulfur - a framework of guidance for agriculture. IUNG Puławy, 53, 1-20 (in Polish).

12. Kabata-Pendias A., Pendias H. 1999. Biogeochemistry of trace elements. PWN Warszawa, 398 pp. (in Polish).

13. Kaniuczak J. 1997. Elements of balance of cadmium and nickel in the loessial soil depended on mineral fertilization. Zeszyty Problemowe Postępów Nauk Rolniczych, PAN, 448a, 197-205 (in Polish).

14. Kaniuczak J. 1998. Research on the evolution of trace elements content in loessial soils. Zeszyty Naukowe AR Kraków, Rozprawy, 244, 98 pp. (in Polish).

15. Kaniuczak J., Hajduk E., Właśniewski S. 2009. The influence of liming and mineral fertilization on manganese and zinc content in potato tubers and green mass of pasture sunflower cultivated in loessial soil. Zeszyty Problemowe Postępów Nauk Rolniczych, PAN, 541, 199-206 (in Polish).

16. Koszelnik-Leszek A. 2003. The sensibility of some spring barley and white mustard varieties on the increased nickel content in soil. Zeszyty Problemowe Postępów Nauk Rolniczych, PAN, 493, 175-184 (in Polish).

17. Liu G., Simonne E.H., Li Y. 2011. Nickel Nutrition in Plants. Hort Sci., UF/IFAS Extension, 1-6.

18. Mohammadzadeh A., Tavakoli M., Chaichi M.R., Motesharezadeh B. 2014. Effects of nickel and PGPBs on growth indices and phytoremediation capability of sunflower (Helianthus annuus L.). Arch Agron Soil Sci., 60 (12), 1765-1778.

19. Mukhtar S., Bhatti H.N., Khalid M., Haq M.A.U., Shahzad S.M. 2010. Potential of sunflower (Helianthus annuus L.) for phytoremediation of nickel $(\mathrm{Ni})$ and lead $(\mathrm{Pb})$ contaminated water. Pak J. Bot., 42 (6), 4017-4026.

20. Najafi F., Khavari-Nejad R.A., Hasanjanzadeh F. 2011. The Physiological responses of sunflower (Helianthus annuus L.) to NiSO4. Afr J. Plant Sci., 5 (3), 201-206.

21. Ordinance of the Minister for Health of 31st January 2003. Journal of Law, number 37, item 326 (in Polish).

22. Öborn I., Jansson G., Johnsson L. 1995. A field study influence of soil $\mathrm{pH}$ on trace element levels in spring wheat (Triticum aestivum), potatoes (Solanum tuberosum) and carrots (Daucus carota). Water Air and Soil Pollution, 85, 835-840.

23. Öztürk E., Atsan E., Polat T., Kara K. 2011. Variation in heavy metal concentrations of potato (Solanum tuberosum L.) cultivars. J. Anim. Plant Sci., 21(2), 235-239.

24. Pakhnenko E.P., Ermakov A.V., Ubugunov L.L. 2009. Influence of Sewage Sludge from Sludge Beds of Ulan-Ude on the Soil Properties and the Yield and Quality of Potatoes. Moscow University Soil Science Bulletin, 64 (4), 175-181.

25. Rosen C.J., Eliason R. 2005. Nutrient Management for Commercial Fruit and Vegetable Crops in Minnesota. Agr. Fod. and Envir. Sci., 40.

26. Sharma A., Dhiman A. 2013. Nickel and cadmium toxicity in plants. J Pharm Sci Innov., 2 (2), 20-24.

27. Shukla R. 2010. Nickel Level and Toxicity and Metabolism of Potato. Inter. J. Veg. Sci., 16 (2), 160-166.

28. Shukla R., Gopal R. 2009. Excess Nickel Alters Growth, Metabolism, and Translocation of Certain Nutrients In Potato. J of Plant Nutr., 32 (6), 1005- 1014.

29. Stasinos S., Zabetakis I. 2013. The uptake of nickel and chromium from irrigation water by potatoes, 
carrots and onions. Ecotoxicology and Environmental Safety, 91,122-128.

30. Stegen S., Queirolo F., Carrasco C. 2002. Concentrations of $\mathrm{Ni}$ and $\mathrm{Co}$ in crop plants cultivated in northern Chile. Bol Soc Chil Quím., 47 (3), 279-287.

31. Szymańska M., Matraszek R. 2005. Reaction of the sunflover (Helianthus annuus L.) to nickel conditioned by the way of metal penetration. Acta Sci Pol. Hortorum Cultus, 4(1), 139-152.

32. Šrek P., Hejcman M., Kunzová E. 2010. Multivariate analysis of relationship between potato (Solanum tuberosum L.) yield, amount of applied elements, their concentrations in tubers and uptake in a long-term fertilizer experiment. Field Crops
Research, 118, 183-193.

33. Šrek P., Hejcman M., Kunzová E. 2012. Effect of long-term cattle slurry and mineral N,P and K application on concentrations of $\mathrm{N}, \mathrm{P}, \mathrm{K}, \mathrm{Ca}, \mathrm{Mg}, \mathrm{As}$, $\mathrm{Cd}, \mathrm{Cr}, \mathrm{Cu}, \mathrm{Mn}, \mathrm{Ni}, \mathrm{Pb}$ and $\mathrm{Zn}$ in peeled potato tubers and peels. Plant Soil Environ., 58 (4), 167-173.

34. Właśniewski S. 2003. Nickel content in selected plant species cultivated in the soil conditions of the Subcarpathian region. Zeszyty Problemowe Postępów Nauk Rolniczych, PAN, 493, 269-278 (in Polish).

35. Zornoza P., Robles S., Martin N. 1999. Alleviation of nickel toxicity by ammonium supply to sunflower plants. Plant and Soil, 208, 221-226. 